Original research article

\title{
Analysis of balance ability in senior age related to quality of life indicators
}

\author{
Milada Krejčí ${ }^{1 *}$, Martin Hill ${ }^{2}$, Dobroslava Jandová ${ }^{1}$, Jiří Kajzar ${ }^{1}$ \\ ${ }^{1}$ College of Physical Education and Sport PALESTRA, Prague, Czech Republic \\ 2 Institution of Endocrinology, Prague, Czech Republic
}

\begin{abstract}
Objectives: In this study, physical balance indicators in relation to seniors' quality of life indicators are analysed. The objective is to analyse balance in the holistic epistemological concept, when physical imbalances have an impact on emotional and social imbalances in ageing. Procedure: Analysed data were collected from 500 randomly chosen seniors, selected from all regions of the Czech Republic. Seniors were in the age of 65 years old and over; there were 234 males (mean: $74.5 S D \pm 7.74$ ) and 266 females (mean: 76.9 SD \pm 7.23 ). Seniors participated voluntarily on the base of the fulfilment of the informed consent.

Methods: Medical Anamnesis; Functional anthropological examination; Tinetti Balance Assessment Tool; RAND 36 Short Form Health Survey (SF-36). Statistics: multivariate regression with reduction of dimensionality, method of orthogonal projection to latent structure. Results: Significant correlations between each of the 36 items of the test "SF-36" and the level of the Tinetti balance test were found. SF36 items are discussed, which have a positive or negative effect on the physical balance of seniors. In addition, anthropological and health factors were analysed, which were in significant correlation to the results of the Tinetti balance test.

Conclusions: Physical balance in seniors 65+ is very closely and significantly related to the SF-36 items. Muscle mass, analysed health and anthropometric indicators have a significant impact on the results of the Tinetti balance test.
\end{abstract}

Keywords: Health Assessment; Physical Balance; Quality of Life Inventory; Seniors' age 65+

\section{Introduction}

The focus on the elderly population from the view of health support and improving seniors' quality of life is a real challenge for all European states, especiallyin the research of factors that effectively influence the healthy life expectancy in aging. The population of European Union is becoming older; the number of people aged sixty-five years or more is increasing. After the year 2025, almost $25 \%$ of Europe's elderly population will be over sixty-five years old. The number of seniors over the age of eighty will increase significantly during that time (European Commission, 2016). In the Czech Republic, just like in the EU, the number of seniors is increasing according to the so-called "inverted pyramid" syndrome. In 2018 in the Czech Republic around 2.8 million people are at retirement age (CSSA, 2018).

In EU states, the program "Active and Healthy Ageing" is applied, which is aimed at increasing the average healthy lifespan of Europeans by 2020, to improve health and quality of life with a focus on seniors. Evaluation of health in effective interventions can help to realize implications for national/international policy. In this way, it is very important to analyse the physical and health awareness level, namely in connection to the physical barriers identified in senior age
(Bártlová, 2018, Michalowski et al., 2018). In the area of the social science aspects, research in the field of health education and public health research, the contributions related to senior physical balance ability and skills are very much accepted; especially from the view of the holistic aspect of health and from a broad bio-psycho-social perspective of the balance, including the economical-medical impact on injury prevention in senior age (above sixty-five years old).

According to Hahn (2015), fear of certain diseases associated with aging (e.g. Diabetes mellitus II. type) also causes anxiety from loss of balance ability and risk of falls. Psychogenic dizziness - vertigo is defined as a feeling of movement, which can be assigned to psychiatric disorders (e.g. anxiety, depression). Psychogenic dizziness occurs in $15 \%$ of patients with vertigo who have a normal diagnosis of balance system (Hahn, 2015). According to Bielaková et al. (2014), the ability to move freely is an important factor that determines the quality of life of the elderly population. This is one of the most common geriatric problems that threaten independence and self-sufficiency in seniors. Instability with its major consequences - falls - is becoming a major problem in health care and has great economic costs. This issue is closely linked with demographic projections in the Czech Republic, which assumes a gradual increase in the number of elderly people, and that is why it must be given due attention.

\footnotetext{
* Author for correspondence: Milada Krejčí, College of Physical Education and Sport PALESTRA, Slovačíkova 400/1, 19000 Prague 9, Czech Republic; e-mail: krejci@palestra.cz http://doi.org/10.32725/kont.2019.017 
The objective of this article is to develop understanding of the bio-psycho-social consequences of balance in senior age and to provide quantitative and qualitative research analyses concerning the physical balance management. Therefore, the main objective is to analyse seniors' balance in holistic epistemological concept, when physical imbalances have an impact on emotional imbalances in ageing, which are reflected in social imbalance consequences.

Based on the stated goal, two hypotheses were established: $\mathbf{H 1}$ - Minimum of 12 selected indicators of Quality of Life examined by SF-36 will be in significant correlation with results of the Tinetti balance test, in the sample of investigated seniors. H2 - Muscle mass will be in significant positive correlation with the results of the Tinetti balance test, in the sample of investigated seniors.

\section{Materials and methods}

The following diagnostic tools were applied during the investigation:

\section{Medical anamnesis}

Medical anamnesis was provided in cooperation with physicians; and basic information of the health condition of the elderly was collected.

\section{Functional anthropological examination}

The examination was created with selected classical anthropometry methods, which were non-invasive, using anthropometric instruments such as an anthropometer, digital personal scale, Harpenden calliper, and manual dynamometer type Collin. The following parameters were examined: height, body weight, BMI, girth of chest across mesosternale, girth of waist, abdominal circumference, gluteal circumference, arm circumference (relaxed), maximum calf circumference, biepicondylar, width of humerus, biepicondylar width of femur, width of wrist, width of ankle, girth of knee, girth of ankle; thickness of seven selected skinfolds - calliper measurement type Harpenden (biceps, triceps, suprailiac, abdominal, subscapular, anterior thigh, calf medial). Body Composition Analysis was completed using In-Body 230. All of the used methods in the Functional anthropological examination were provided according to thedescription in Bláha (2017).

\section{Tinetti Balance Assessment Tool}

The Tinetti Balance Assessment Tool evaluates the balance ability score of seniors and serves to evaluate the results of the intervention. It evaluates the overall balance score from the following components: static balance and gait. In this study we analyse the results of the investigated seniors in the static balance of the Tinetti balance test (Janečková et al., 2013; Tinetti et al., 1986).

\section{RAND 36 Short Form Health Survey (SF-36)}

The RAND 36-Item Short Form Survey (SF-36) is a widely used tool to determine the quality of life related to health in seniors. In general, the questionnaire SF-36 is sensitive to all areas of physical, mental and social health problems caused by aging. It consists of 36 questions grouped into 9 categories (see Table 1). The SF-36 is a tool managed by the non-profit organization RAND Corporation. The authors are Ware, Snow, Kosinski, Gandek (Ware et al., 1993). The authors of the original Czech translation are Sobotík and Petr (ÚZIS ČR, 2018).
Table 1. Relationships between analysed Static Balance examined by Tinetti Balance Assessment Tool/BS and indicators of Quality of Life examined by SF-36, evaluated by OPLS model ( $n=500 ; 234$ males, 266 females)

\begin{tabular}{|c|c|c|c|c|c|}
\hline & \multirow[b]{2}{*}{ Variable } & \multicolumn{4}{|c|}{ Predictive component, OPLS } \\
\hline & & $\begin{array}{l}\text { Component } \\
\text { loading }\end{array}$ & t-statistics & $R^{\mathrm{a}}$ & \\
\hline \multirow{36}{*}{$(\operatorname{matrix} X)$} & Question 1 & -0.151 & -6.52 & -0.468 & $* *$ \\
\hline & Question 2 & -0.086 & -6.09 & -0.266 & $* *$ \\
\hline & Question 3 & 0.155 & 15.56 & 0.478 & $* *$ \\
\hline & Question 4 & 0.255 & 16.98 & 0.788 & $* *$ \\
\hline & Question 5 & 0.234 & 24.64 & 0.723 & $* *$ \\
\hline & Question 6 & 0.234 & 24.01 & 0.723 & $* *$ \\
\hline & Question 7 & 0.246 & 36.95 & 0.761 & $* *$ \\
\hline & Question 8 & 0.235 & 22.09 & 0.726 & $* *$ \\
\hline & Question 9 & 0.260 & 18.34 & 0.804 & $* *$ \\
\hline & Question 10 & 0.253 & 14.92 & 0.781 & $* *$ \\
\hline & Question 11 & 0.230 & 18.71 & 0.710 & $* *$ \\
\hline & Question 12 & 0.225 & 32.85 & 0.695 & $* *$ \\
\hline & Question 13 & 0.078 & 4.43 & 0.242 & $* *$ \\
\hline & Question 14 & 0.068 & 3.83 & 0.211 & $* *$ \\
\hline & Question 15 & 0.116 & 9.25 & 0.359 & $* *$ \\
\hline & Question 16 & 0.110 & 10.30 & 0.341 & ** \\
\hline & Question 17 & 0.082 & 4.37 & 0.253 & $* *$ \\
\hline & Question 18 & 0.053 & 2.36 & 0.163 & $*$ \\
\hline & Question 19 & 0.050 & 2.44 & 0.156 & $*$ \\
\hline & Question 20 & -0.109 & -3.63 & -0.337 & $* *$ \\
\hline & Question 21 & -0.072 & -3.33 & -0.221 & $* *$ \\
\hline & Question 22 & -0.115 & -6.28 & -0.355 & $* *$ \\
\hline & Question 23 & -0.123 & -5.78 & -0.379 & $* *$ \\
\hline & Question 24 & 0.061 & 3.03 & 0.188 & $* *$ \\
\hline & Question 25 & 0.093 & 3.34 & 0.287 & $* *$ \\
\hline & Question 26 & -0.084 & -3.12 & -0.260 & $* *$ \\
\hline & Question 27 & -0.125 & -6.93 & -0.388 & $* *$ \\
\hline & Question 28 & 0.096 & 3.64 & 0.296 & ** \\
\hline & Question 29 & 0.121 & 5.42 & 0.373 & $* *$ \\
\hline & Question 30 & -0.094 & -3.90 & -0.290 & ** \\
\hline & Question 31 & 0.116 & 7.45 & 0.357 & $* *$ \\
\hline & Question 32 & 0.135 & 7.05 & 0.418 & $* *$ \\
\hline & Question 33 & 0.111 & 6.13 & 0.344 & ** \\
\hline & Question 34 & -0.098 & -4.05 & -0.303 & $* *$ \\
\hline & Question 35 & 0.115 & 11.53 & 0.356 & ** \\
\hline & Question 36 & -0.131 & -6.12 & -0.404 & ** \\
\hline$($ matrix $Y)$ & $\begin{array}{l}\text { Tinetti, } \\
\text { balance }\end{array}$ & 1.000 & 35.02 & 0.695 & ** \\
\hline \multicolumn{2}{|c|}{ Explained variability } & \multicolumn{3}{|c|}{$48.3 \%$ ( $43.8 \%$ after cross-validation) } & \\
\hline $\begin{array}{l}{ }^{\mathrm{a}} \mathrm{R}-\mathrm{Com} \\
\text { predictive }\end{array}$ & 1 & $05 * *$ & 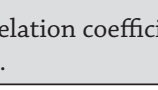 & with & \\
\hline
\end{tabular}

\section{Statistics}

For the statistic evaluation we chose multivariate regression with reduction of dimensionality, such as the method of orthogonal projection to latent structure (OPLS) thatis capable of copingwith the problem of multicollinearity, which is expectednamely in the anthropometric data (Best and Wolf, 2014; Meloun et al., 2002).

\section{Material, ethical issues}

Analysed data were collected from 500 randomly chosen seniors, selected from all regions of the Czech Republic. Seniors were selected from senior homes, retirement homes, and seniors' centres/clubs. Investigated seniors were in the age range of 65 years old and over (mean: $75.9 S D \pm 7.14$ ), e.g., 234 males in the age: mean: $74.5 S D \pm 7.74$, median: $71.0(67.0,80.0)$ and 266 females in the age: mean: $76.9 S D \pm 7.23$, median: 76.0 
(66.0, 84.0). All seniors participated in the research project voluntarily. Each senior was informed about the research and signed a consent form for voluntary participation.

\section{Results and discussion}

From the analysed results that focused on correlations between indicators of quality of life examined by SF-36 and the results of the Tinetti balance test, it is evident that each of all SF-36 questions (indicators of senior quality of life) are significant to the static balance ability examined by the Tinetti Balance Assessment Tool.

The results are based on the correlation coefficients with predictive component at $p<0.05$, which includes components of the category "Restrictions caused by emotional problems", namely question 18: "Accomplished less than you would like" and question 19: "Didn't do work or other activities as carefully as usual". The next results are based on the correlation coefficients with predictive component $p<0.01$, which includes components of all other categories (see Table 1, Table 2).

These results of the statistical analysis confirm the validity of the hypothesis $\mathrm{H} 1$ that: "A minimum of 12 selected indicators of Quality of Life (examined by SF-36) will be in significant correlation with results of the Tinetti balance test in the sample of investigated seniors". These results of the statistical analysis also confirm a high reliability of the RAND 36 Short Form Health Survey (SF-36) in the monitored population of seniors aged sixty-five years and over.

Table 2. Overview of questions of the RAND 36 Short Form Health Survey (SF-36), divided into 9 categories

\section{Overall perception of health}

1. In general, would you say your health is: Excellent; Very good; Good; Fair; Poor?

2. Compared to one year ago, how would you rate your general health now? Much better than one year ago; Somewhat better than one year ago; About the same; Somewhat worse than one year ago; Much worse than one year ago.

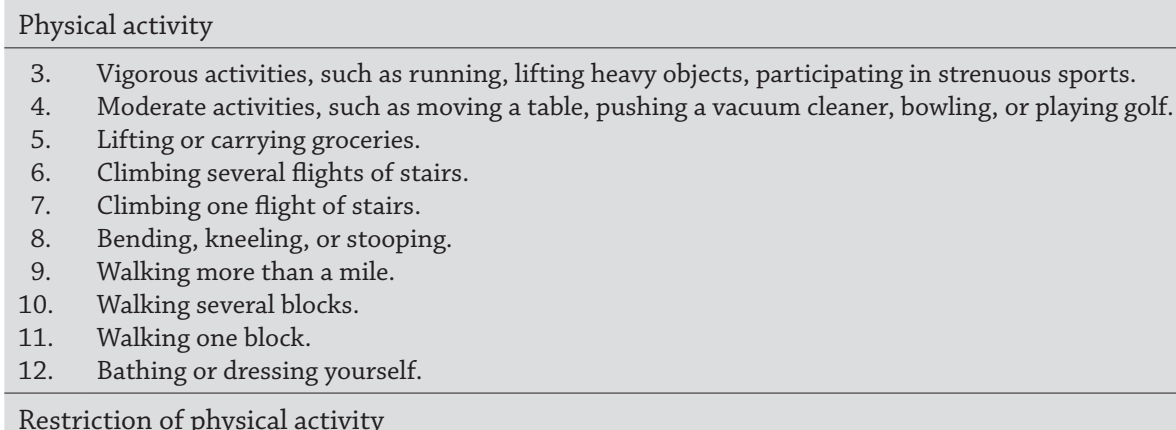

13. Cut down the amount of time you spent on work or other activities.

14. Accomplished less than you would like.

15. Were limited in the kind of work or other activities.

16. Had difficulty performing the work or other activities (for example, it took extra effort).

Restriction caused by emotional problems

17. Cut down the amount of time you spent on work or other activities.

18. Accomplished less than you would like.

19. Did not do work or other activities as carefully as usual.

Social activity

20. During the past 4 weeks, to what extent have your physical health or emotional problems interfered with your normal social activities with family, friends, neighbours, or groups?

Pain

21. How much bodily pain have you had during the past 4 weeks?

22. During the past 4 weeks, how much did pain interfere with your normal work (including both work outside the home and housework)?

Vitality, neurosis, depression

23. Did you feel full of pep?

24. Have you felt like a very nervous person?

25. Have you felt so down in the dumps that nothing could cheer you up?

26. Have you felt calm and peaceful?

27. Did you have a lot of energy?

28. Have you felt downhearted and blue?

29. Did you feel worn out?

30. Have you been a happy person?

31. Did you feel tired?

Social activity

32. During the past 4 weeks, how much of the time have your physical health or emotional problems interfered with your social activities (like visiting friends, relatives, etc.)? 
Table 2 (Continued)

Health change
33. I seem to get sick a little easier than other people.
34. I am as healthy as anybody I know.
35. I expect my health to get worse.
36. My health is excellent.

It was analysed that the answers "poor perception of health" and "much worse perception of health compared to one year ago" (Question 1, Question 2, Category "Overall perception of health") correlated significantly negatively with the results of seniors static balance in the Tinetti balance test $(p<0.01)$. Also, the negative impact on the static balance of seniors, examined by the Tinetti balance test, had situations in which during the past 4 weeks of the senior's life, physical health problems or emotional problems interfered with normal social activities with family, friends, neighbours, or groups (Question 20, Category "Social activity"). The reduction of social activities may be associated with the low self-esteem of seniors in the "health change" category, especially in trusting one's health (questions 34,36 ). It was also found that the neg- ative impact on static balance ability in seniors also had components of a high level of "Pain" (Question 21, 22) and a high level of "Nervousness" (Question 24). It can be expressed that the actual emotional state has a significant influence on the physical balance ability in seniors, whereby the advantage is in emotional stability "to be calm and balanced", as the authors of the studies confirmed (Cho et al, 2011; Marcinko 2015).

On the other hand, categories such as "sufficient physical activity", "the ability to perform it well" and "no limitations due to physical or emotional problems" correlated significantly positively with the static balance in the Tinetti balance test (see Table 2, Chart 1). These findings are consistent with the published results in the studies of Marcinko (2015) and Janečková et al. (2013).

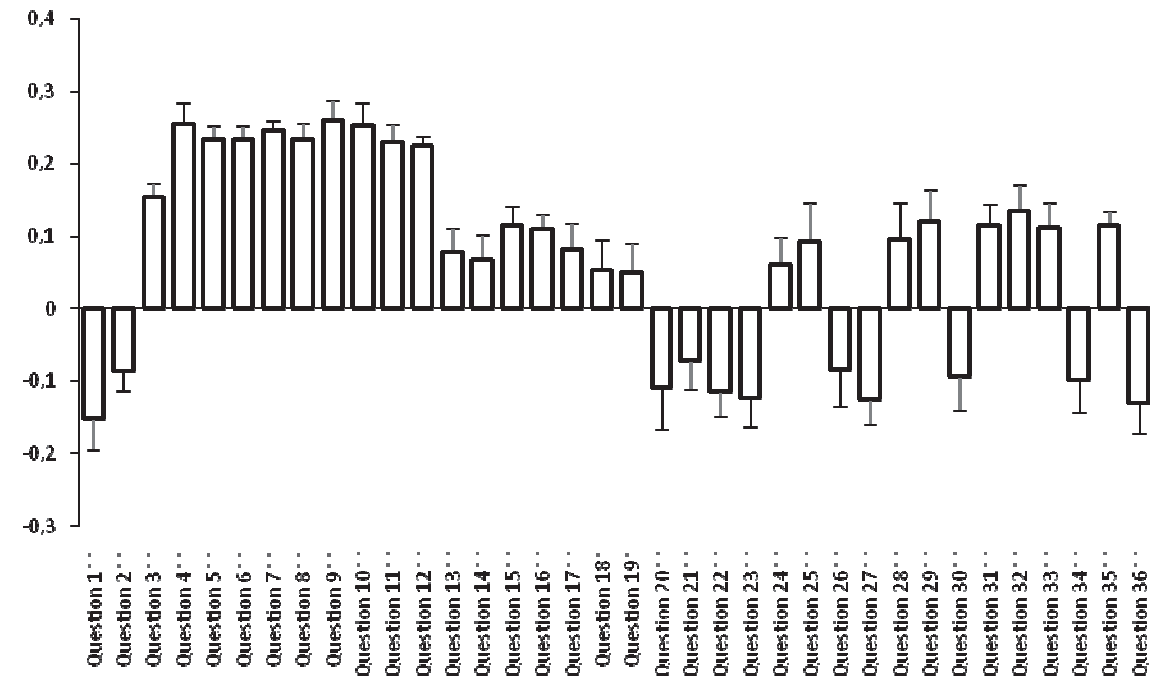

Chart 1. Indicators of Quality of Life examined by SF-36 with positive or negative influence on the Static Balance Ability examined by Tinetti Balance Assessment Tool/BS, evaluated by OPLS model ( $n=500 ; 234$ males, 266 females)

The medical anamnesis results and the functional anthropological examination have shown that diseases such as diabetes, hypertension, and heart problems are significant risk factors for the results of static balance in the Tinetti balance test (see Table 3, Chart 2). Also, the number of medicaments has a significant negative effect on the static balance ability. Medicaments consumption in the monitored seniors' population represented (on average) 4-6 medicaments daily, with no significant differences between the genders. It could also cause allergy problems. In the analysis of the monitored seniors, we found (on average) at least one allergy per person, with no significant differences between the genders. Some medicaments can contribute to the static balance problems. An intervention in health literacy, in accordance with Michalowski et al. (2018), can be very useful.
On the basis of the provided statistical analyses it was discovered that muscle mass correlates significantly positively with the ability of static balance by Tinetti balance test in the investigated seniors (correlation coefficients with predictive component $p<0.01$ ), see Table 3 , Chart 2 . This result of the statistical analysis confirms the validity of the hypothesis $\mathrm{H} 2$ : "Muscle mass will be in significant positive correlation with the results of the Tinetti balance test in the sample of investigated seniors." According to the study of the authors Barbarino and Bura (2017), it can be argued that the application of statistical analysis of multivariate regression with the reduction of dimensionality has been well chosen in its ability to linearly reduce the dimensionality of a given multivariate data set. The effective number of major components made possible the maximum amount of size reduction without destroying 
Table 3. Relationships between analysed Balance Ability examined by Tinetti Balance Assessment Tool/BS and selected indicators of Functional anthropological examination, evaluated by OPLS model ( $n=500 ; 234$ males, 266 females)

\begin{tabular}{|c|c|c|c|c|c|}
\hline & & Predict & e componen & , OPLS & \\
\hline & Variable & $\begin{array}{l}\text { Component } \\
\text { loading }\end{array}$ & $t$-statistics & $R^{\mathrm{a}}$ & \\
\hline & Diabetes & -0.117 & -6.53 & -0.363 & *** \\
\hline & Hypertension & -0.048 & -2.55 & -0.148 & $*$ \\
\hline & Heart problem & -0.078 & -2.20 & -0.241 & * \\
\hline & Medication & -0.137 & -6.32 & -0.424 & ** \\
\hline & Age & -0.171 & -5.97 & -0.528 & \\
\hline (matrix & Muscle Mass & 0.064 & 4.48 & 0.180 & ** \\
\hline$X)$ & Biepicondylar & & & & \\
\hline & width of femur & 0.127 & 11.45 & 0.371 & ** \\
\hline & Girth of chest & 0.059 & 8.35 & 0.164 & ** \\
\hline & Girth of knee & 0.070 & 3.67 & 0.201 & ** \\
\hline & Girth of ankle & 0.050 & 6.63 & 0.137 & ** \\
\hline & Girth of wrist & 0.053 & 2.77 & 0.151 & * \\
\hline $\begin{array}{c}\text { (matrix } \\
Y \text { ) }\end{array}$ & $\begin{array}{l}\text { Tinetti, } \\
\text { balance }\end{array}$ & 1.000 & 35.02 & 0.695 & ** \\
\hline Explaine & variability & $48.3 \%$ (43. & $\%$ after cross- & ralidation & \\
\hline $\begin{array}{l}\text { a } R-\text { Cor } \\
\text { predictiv }\end{array}$ & $\begin{array}{l}\text { nent loadings } \\
\text { mponent; }{ }^{*} p\end{array}$ & $\begin{array}{l}\text { ressed as co } \\
05 ;{ }^{* *} p<0 .\end{array}$ & ation coeff & nts wit & \\
\hline
\end{tabular}

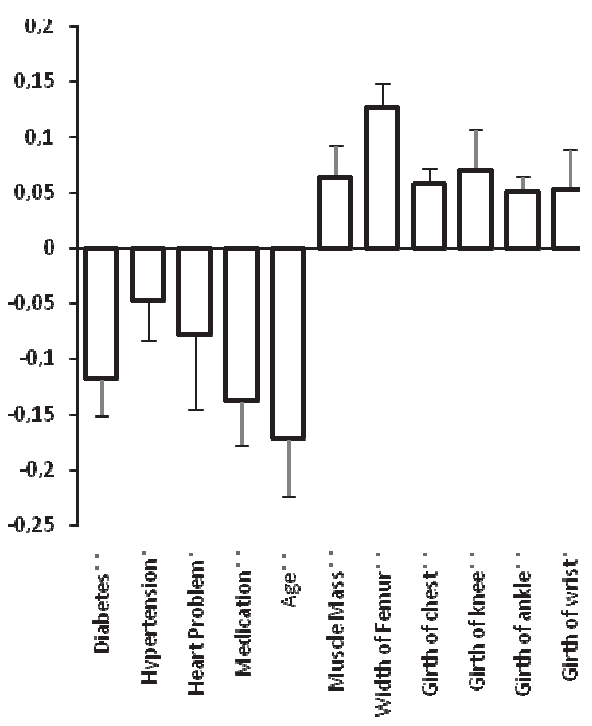

Chart 2. Selected indicators of Functional anthropological examination with positive or negative influence on the Balance Ability examined by Tinetti Balance Assessment Tool/BS, evaluated by OPLS model ( $n=500 ; 234$ males, 266 females)

the valid information. On the other hand, it was found that higher age and aging significantly negatively correlates with the ability of static balance according to the Tinetti balance test. It can be therefore, that in higher age the muscle mass is reduced - as Hahn (2015) expresses in the context of balance risks in seniors.

Statistical analysis has shown that muscle mass has a significantly positive impact on static balance performance, as do selected anthropometric indicators such as: biepicondylar width of femur, girth of chest, girth of knee, girth of ankle and girth of wrist, which correlates significantly positively with the results in the static balance examined in the monitored seniors (correlation coefficients with predictive component $p<0.01$ ), see Table 3 , Chart 2 . The biepicondylar width of the femur provides information on the robustness of the skeleton as is mentioned by Bláha (2017). It can be discussed in accordance with Bláha (2017) that a certain robust character of the body, in the good sense, can represent an advantage in maintaining static balance ability and can play a positive role in the prevention of injuries and falls in senior age. According to Janečková et al. (2013) and Krejčí and Kornatovská (2017), it is very important to discuss the individual possibility of motivating a senior to manage the ability to provide adequate physical activity sequences according to the breathing capacity and to relax and unblock emotional and social tensions, which seems to be very effective in terms of static balance ability development in seniors, aged sixty-five and over.

\section{Conclusions}

It is possible to conclude that the purpose of analysing relations between balance ability in senior age and quality of life indicators represents a significant contribution when dealing with ethical issues in health care, risk management and the impact on physical balance in senior age. The results can be summarized as follows. Established hypotheses have been confirmed. The first hypothesis confirmed that there are correlations between indicators of quality of life, examined by SF36 questionnaire, with results of the Tinetti balance test. Low self-perception, negative emotions and depression negatively influence the static balance at a significance of $p<0.01$. Also, in terms of the negative impact on the static balance of examined seniors there were situations when physical health problems or emotional problems interfered with daily social activities with family, friends, neighbours, or groups $(p<0.01)$. The reduction of normal social activities is related to the disbelief in one's own good health. Furthermore, it was analysed that pain and nervousness have a negative effect on the ability of static balance.

It was confirmed in the second hypothesis that muscle mass correlates positively with the results of the Tinetti balance test in the sample of investigated seniors $(p<0.01)$.A positive influence on the static balance ability in seniors was found in correlation with a certain body robustness, which can be the result of work and physical activities during life. We recommend regular practice oriented toward the development of static balance ability that is applied in work with seniors in senior homes, centres, clubs, etc.

The research provides clear evidence that physical balance is improved by involvement in demanding daily tasks. We found social involvement to be beneficial. This is particularly important because the productive engagement potentially self-reinforces the physical balance stimulation. It is very important to determine that static balance development represents the facilitation for emotional and social balance development in senior age. The results of the study can be inspiring for the research application in the field of health and social care.

\section{Conflict of interests}

The authors have no conflict of interests to declare.

\section{Acknowledgement}

The presented research was supported and funded by the Czech Science Foundation - project GACR ID 17-25710S "Basic Research of Balance Changes in Seniors". 


\section{Analýza balančních schopností v seniorském věku v souvislosti s ukazateli kvality života}

\section{Souhrn}

Cíle: V této studii jsou analyzovány ukazatele fyzické rovnováhy ve vztahu k ukazatelům kvality života seniorů. Cílem je analyzovat rovnováhu v holistickém epistemologickém pojetí, kdy fyzická nerovnováha ve stáří má vliv na nerovnováhu emocionální a sociální.

Postup: Analyzovaná data byla získána od 500 náhodně vybraných seniorů vybraných ze všech krajů ČR. Senioři byli ve věku 65 let a více; 234 mužů (věkový průměr: 74,5 $S D \pm 7,74$ ) a 266 žen (věkový průměr: 76,9 $S D \pm 7,23$ ). Senioři se účastnili výzkumného šetření dobrovolně na základě předem uzavřeného informovaného souhlasu.

Metody: Lékařská anamnéza; Funkční antropologické vyšetření; Tinetti balanční škála; Dotazník kvality života SF-36. Statistika: vícerozměrná regrese s redukcí rozměrnosti, metoda ortogonální projekce do latentní struktury.

Výsledky: Byly nalezeny významné korelace mezi každou z 36 položek testu „SF-36“ a úrovní testu statické rovnováhy dle Tinetti. Jsou diskutovány položky SF-36, které mají pozitivní nebo negativní vliv na fyzickou rovnováhu seniorů. Dále byly analyzovány antropologické a zdravotní faktory, které významně korelovaly s výsledky testu statické rovnováhy dle Tinetti.

Závěr: Fyzická rovnováha u seniorů $65+$ je velmi úzce a signifikantně spojena s položkami SF-36. Množství svalové hmoty a další analyzované zdravotní a antropometrické indikátory mají signifikantní vliv na výsledky testu statické rovnováhy dle Tinetti.

Klíčová slova: hodnocení zdraví; fyzická rovnováha; dotazník kvality života SF-36; seniorský věk 65+

\section{References}

1. Barbarino A, Bura E (2017). A unified framework for dimension reduction in forecasting. Finance and economics discussion series 2017-004. Washington: Board of Governors of the Federal Reserve System. DOI: 10.17016/FEDS. 2017.004.

2. Bártlová $S$ (2018). Health literacy in selected population groups. Kontakt 20(4): e317-e318. DOI: 10.1016/j. kontakt.2018.10.012.

3. Best H, Wolf C (2014). The SAGE handbook of regression analysis and causal inference. London: Sage.

4. Bielaková K, Matějovská Kubešová H, Weber P (2014). Prevence a management instability a pádů u geriatrických pacientů. Geriatrie a Gerontologie 3(1): 25-28.

5. Bláha P (2017). Funkční a sportovní antropologie - vybrané metody. Praha: Vysoká škola tělesné výchovy a sportu PALESTRA.

6. Cho J, Martin P, Margrett J, Macdonald M, Poon LW (2011). The relationship between physical health and psychological well-being among oldest-old adults. J Aging Res 2011: 605041. DOI: $10.4061 / 2011 / 605041$.

7. Czech Social Security Administration (CSSA) (2018). Přehled o počtu poplatníků pojistného a počtu důchodců. [online] [cit. 2019-02-17]. Available from: https://www.cssz.cz/cz/o-cssz/ informace/statistiky/ekonomicke-ukazatele/prehled-vybranychstatistickych-a-ekonomickych-ukazatelu/prehled-vybranychstatistickych-a-ekonomickych-ukazatelu.htm

8. European Commission (2016). The 2016 Call for Commitments of the European Innovation Partnership on Active and Healthy Ageing. Ec.europa.eu 10/02/2016. [online] [cit. 2018-02-12]. Available from: https://ec.europa.eu/eip/ageing/news/2016call-commitments-european-innovation-partnership-activeand-healthy-ageing-open_en
9. Hahn A (2015). Otoneurologie a tinitologie. Praha: Grada.

10. Janečková $\mathrm{B}$, Szabó K, Kalová $\mathrm{H}$, Poncarová E, Voštová $\mathrm{M}$, Petr $\mathrm{P}$ (2013). Riziko pádů v ambulantní a stacionární péči. Prevence úrazů, otrav a násilí 9(2): 129-134.

11. Krejčí M, Kornatovská Z (2017). Yoga applications in persons with disabilities. In: Bolach E, Kawczynski A (Eds). Adaptacyjna Aktywnoscz Fizyczna. Wroclaw: AWF.

12. Marcinko I (2015). The moderating role of autonomous motivation on the relationship between subjective well-being and physical health. PloS One 10(5): e0126399. DOI: 10.1371/ journal.pone.0126399.

13. Meloun M, Militky J, Hill M, Brereton RG (2002). Crucial problems in regression modelling and their solutions. Analyst 127(4):433-450.

14. Michalowski M, Austin RR, Mathiason MA, Maganti S, Schorr E, Monsen KA (2018). Relationships among interventions and health literacy outcomes for sub-populations: A data-driven approach. Kontakt 20(4): e319-e325. DOI: $10.1016 /$ j.kontakt.2018.10.009.

15. Tinetti ME, Williams TF, Mayewski R (1986). Fall Risk Index for elderly patients based on number of chronic disabilities. Am J Med 80(3): 429-434. DOI: 10.1016/0002-9343(86)90717-5.

16. ÚZIS ČR (2018). Dotazník kvality života SF-36. [online] [cit. 2019-01-10]. Available from: https://www.uzis.cz/dotaznikkvality-zivota-sf-36

17. Ware JE, Snow KK, Kosinski M, Gandek B (1993). SF-36 Health Survey Manual and Interpretation Guide. Boston: The Health Institute Boston. 